\title{
Antigen-presenting cell-derived extracellular vesicles in accelerating atherosclerosis
}

\author{
Alexander E Berezin ${ }^{1} *{ }^{*}$, Alexander A Berezin ${ }^{2}$
}

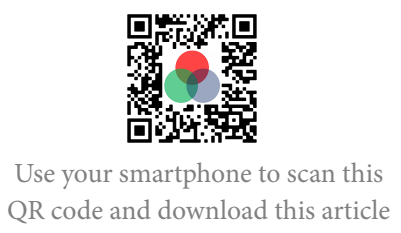

${ }^{1}$ Department of Internal Medicine, State Medical University, Zaporozhye, 69035, Ukraine

${ }^{2}$ Department of Internal Medicine, Medical Academy of Post-graduating

Education, Zaporozhye, 69000, Ukraine

Correspondence

Alexander E Berezin, Department of Internal Medicine, State Medical University, Zaporozhye, 69035, Ukraine.

Email: aeberezin@gmail.com

History

- Received: Jan 17, 2021

- Accepted: Mar 26, 2021

- Published: Mar 31, 2021

DOI : 10.15419/bmrat.v8i3.664

\section{Check for updates}

\section{Copyright}

(c) Biomedpress. This is an openaccess article distributed under the terms of the Creative Commons Attribution 4.0 International license.

\begin{abstract}
Extracellular vesicles (EVs) are a population of heterogeneous particles that originate from the endosomal system or plasma membrane. Antigen-presenting cells (APCs) produce and release a broad spectrum of EVs involved in the pathogenesis of atherosclerosis. APC-derived EVs contain several bioactive molecules, such as non-coding RNAs, cytokines, chemokines, active proteins, immunomodulatory factors, and growth factors. The review focuses on the role of APC-derived EVs in regulating the transformation of macrophage phenotype, shaping foam cells, driving autophagy and/or inhibiting apoptosis of $\mathrm{Th}^{+}{ }^{+}$cells, T regulatory cells, endothelial and smooth muscle cells (SMCs), as well as in facilitating oxidative stress in vasculature. APC-derived EVs act as triggers of angiogenesis, neovascularization and inflammation through their participation in microvascular inflammation, angiogenesis, development of atherosclerotic plaques, and modulation of their instability.

Key words: antigen-presenting cells, atherosclerosis, endothelial dysfunction, extracellular vesicles, inflammation, netosis, vascular reparation
\end{abstract}

\section{INTRODUCTION}

During the last two decades, extracellular vesicles (EVs) have become a subject of scrutiny in various diseases $^{1-3}$. EVs are defined as heterogeneous groups of membrane-enclosed spherical structures with variable sizes and compositions, including microvesicles, exosomes and apoptotic bodies ${ }^{4}$. They are secreted by a wide array of cells, including cardiac myocytes, mature and progenitor endothelial cells, mesenchymal stem cells, immune cells like antigen-presenting cells (APCs), and malignant cells ${ }^{5,6}$. Being involved in the transfer of cellular content (e.g. regulatory proteins, hormones, lipids, growth factors, chromatin materials, and microRNAs), EVs play a multifaceted role in cell-to-cell communication, regulation of immune response, tissue reparation, angiogenesis, inflammation and malignancy, via acting as signal transductors which mediate information by internalization of their contents through fusion with the plasma membrane of target cells or through endocytosis ${ }^{7-10}$.

Atherosclerosis is defined as a chronic progressive disease of the arterial wall having a long asymptomatic phase. The development of the disease is associated with microvascular inflammation and altered immune reaction due to strong infiltration of intima and sub-intima by oxidized lipids, oxidative stress, proliferative responses from cellular components of intima and media, accumulation of extra- cellular components with the shaping of atherosclerotic plaques, impaired vasomotion ability, endothelial dysfunction, and thrombosis, ultimately resulting in vascular remodeling and artery obstruction ${ }^{11,12}$. Finally, there is a close relationship between a risk of all-cause mortality and incident of fatal and non-fatal cardiovascular $(\mathrm{CV})$ events in the general population and subclinical atherosclerosis ${ }^{13}$.

Numerous animal studies as well as observational and clinical trials have shown that atherosclerosis arises from immune activation, with several cell-type specific pathways involved. These include macrophage and smooth muscle cell (SMC) phenotypic switching and various inflammatory signaling, such as IL33/suppression of tumorigenesis 2 (ST2), Ras-RafMEK-ERK pathways, and JAK-STAT signaling pathways $^{14-17}$. Besides, some chronic infections induced by pathogens such as Helicobacter pylori and herpes zoster can increase the risk of atherosclerosis, mediating the presence of HSP60-specific T lymphocytes in peripheral blood ${ }^{18,19}$. However, the innate molecular mechanisms involved in the progression of stable artery lesions to the formation of vulnerable plaques still remain uncertain ${ }^{20}$. There is a wide range of evidence regarding the fact that pro-atherogenic factors (e.g. hypoxia, oxidative stress, oxidized lipids, and inflammation) and aggravating factors (e.g. blood flow turbulence, endothelial dysfunction, and vasoconstriction) influence the production of EVs from 
various cells and promote atherosclerosis ${ }^{21,22}$. It has been defined that EVs derived from APCs regulating key steps of disease pathogenesis, such as microvascular inflammation, immunity, cell survival, apoptosis, angiogenesis, thrombosis and autophagy, exert a role in the development of atherosclerotic lesions ${ }^{21,23}$. The review is to update the current evidence of the role of EVs derived from immune cells and APCs in the development of atherosclerotic plaque and modulation of their instability.

\section{DEFINITION AND NOMENCLATURE OF EXTRACELLULAR VESICLES}

The recently updated guideline of the International Society for Extracellular Vesicles (ISEV) on minimal information for studies of extracellular vesicles (MISEV) has defined EVs as "particles naturally released from the cell that is delimited by a lipid bilayer and cannot replicate" ${ }^{24}$. The nomenclature, main characteristics, and biological function of several subpopulations of EVs are reported in Table 1. Exosomes, microvesicles, and apoptotic bodies are validated to describe several types of particles. Although different subpopulations of EVs have a particular and unique morphological structure, which is a result of their origin, EVs can be substantially distinguished from each other in terms of their components, such as cell organelles (endoplasmic reticulum, Golgi, mitochondrial and nuclear components), cytosolic and cytoskeleton proteins (heat shock proteins, tubulins, moesin, cofilins, actin, myosin, protocadherin, apolipoproteins), lipids (cholesterol, sphingomyelin, ceramide, phosphatidylcholine, ethanolamine, and inositol), eicosanoids, enzymes (phospholipases, matrix metalloproteinases), adhesion molecules (CD44, EPCAM, ICAMs, integrins), genetic materials (chromatin debris, DNA, non-coding and coding RNAs), and growth factors (vascular endothelial growth factor [VEGF], epidermal growth factor [EGF], fibroblast growth factor [FGF] and their receptors [EGF and FGF receptors], interleukins, and other biomolecules) ${ }^{25,26}$. Some components (cytosolic and cytoskeleton proteins, growth factors and their receptors, MHC molecules, and adhesive molecules) are constitutively present in various subtypes of EVs. Other components, such as prions and $\beta$-amyloid peptides, occur in pathological condition. Moreover, there is no strong correlation between the components, the size, and the number of these particles in circulation ${ }^{27}$. Despite protein/lipid profiles, as well as nucleic acid species, which could serve as markers for quantitative and compositional characterizations of several subtypes of EVs, there is a need to use other criteria including size, immune phenotype, bilayer morphology, labeling with fluorescent lipids, proteins, or antibodies- to discriminate EVs from each other.

\section{EVS DERIVED FROM IMMUNE AND ANTIGEN-PRESENTING CELLS: BIOLOGICAL ROLE AND FUNCTION}

EVs are produced by immune cells and APCs (macrophages, B cells, dendritic cells) facilitate cellto-cell communication processes, such as forming immune synapses between APCs and T cells, promoting the delivery of peptide complexes of class II major histocompatibility complex (pMHC-II) molecules, and assisting in the differentiation of $\mathrm{T}$ cells into $\mathrm{CD}^{+}$or $\mathrm{CD}^{+} \mathrm{T}$ cells. Besides, they can act as antigen-presenting EVs, thereby mediating the initiation, expansion, maintenance, or silencing of adaptive immune responses, while also promoting differentiation of regulatory $\mathrm{T}$ lymphocytes, inflammation, and apoptosis ${ }^{27,28}$. Therefore, EVs- especially exosomes, which are secreted by naïve human monocytes/macrophages are involved in regulating the phagocytic activity of activated macrophages as a result of the transfer of interleukin (IL)-10 and transforming growth factor (TGF)-beta. It has been found that numerous microRNAs $(-27 \mathrm{a},-29 \mathrm{~b},-125 \mathrm{a}$, -146a, -155, and -222), which are transmitted from naïve human monocytes to macrophages, were powerful triggers for the polarization of macrophages into M2 phenotype ${ }^{29-31}$. Nevertheless, proliferation and differentiation of progenitor endothelial precursors, which are crucial for angiogenesis and neovascularization, are under regulation by APC-derived $\mathrm{EVs}^{32}$. Well-known inductors of cell differentiation, such as circulating oxidase low-density protein and cellfree microRNAs cannot strongly support epigeneticrelated regulation of proliferative activity of resident cells in the vasculature. Several microRNAs (such as microRNA-128, microRNA-128-1, microRNA-148a, microRNA-130b and microRNA-301b) are cargoes for EVs and act as specifically-designed core posttranscriptional regulators of target genes involved in cellular lipid homeostasis, microvascular inflammation, and energy metabolism. These target genes include LDL receptor, ATP-binding cassette transporter A1, sirtuin 1 , and insulin receptor substrate $1^{33-35}$. Thus, specific proteomic, transcriptomic, and lipidomic profiles of EVs secreted by immune cells and APCs are engaged in control of migration, proliferation and differentiation of recipient cells. 


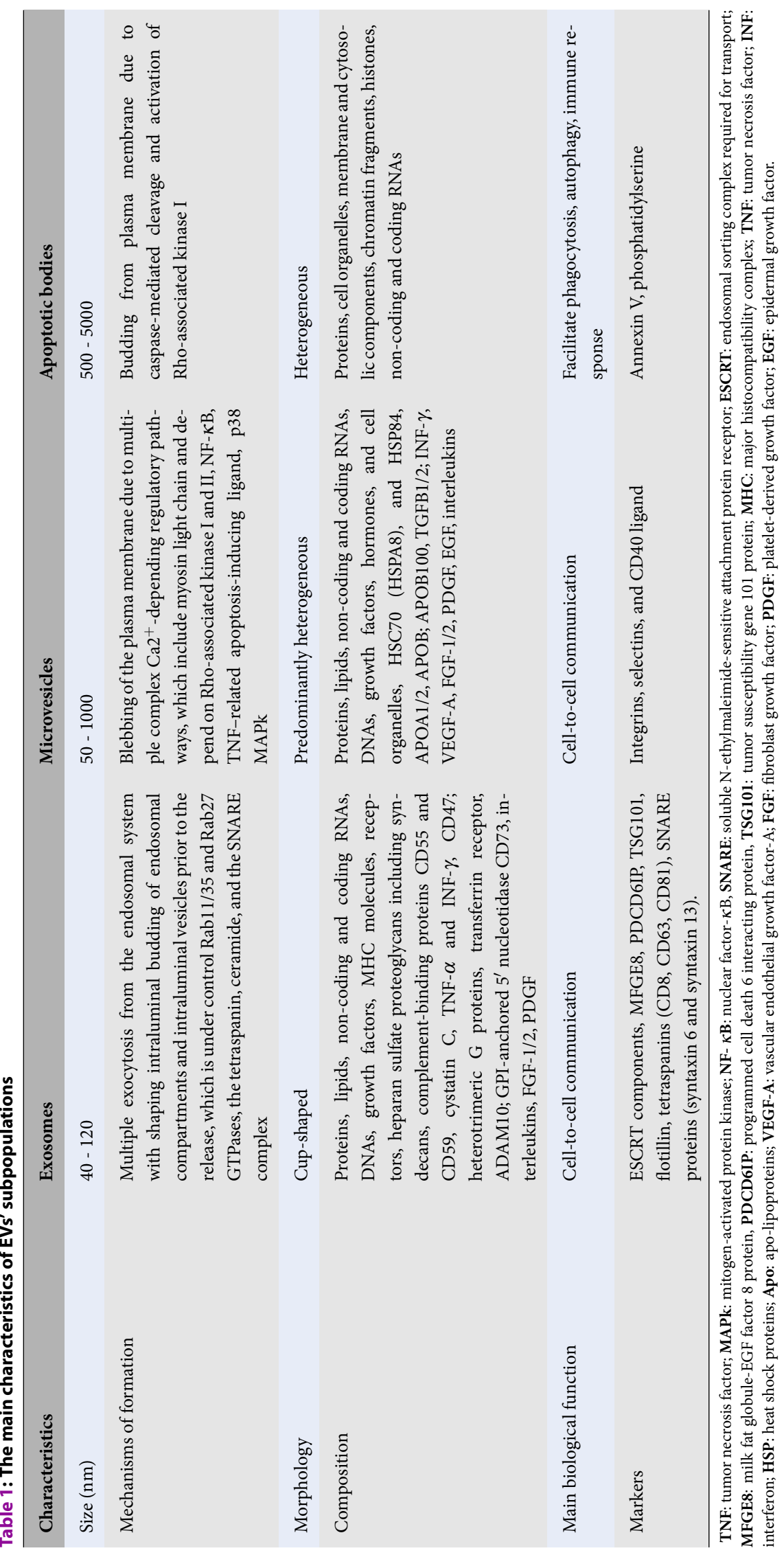




\section{IMMUNE AND APC-DERIVED EVS IN ATHEROSCLEROSIS}

Previous preclinical and clinical studies have revealed that EVs are associated with the presence, progressiveness, and severity of atherosclerosis ${ }^{36-38}$. Indeed, circulating levels of EVs have been found to be increased in atherosclerosis, and EVs were EVs involved in key stages of atherosclerosis progression, such as accumulation of lipid, thickness of intima, proliferative response from SMCs, promotion of vascular media and calcification, plaque shaping and progression, and thrombus formation after plaque rupture ${ }^{36}$. The proliferation and migration of macrophages, epithelial cells and vascular SMCs, as well as the transformation of macrophages into foam cells, are all essential elements for the formation of atherosclerotic plaques and acceleration of atherosclerosis ${ }^{37}$. Activated macrophages can interact with vascular SMCs through exosomes and stimulate them to migrate and adhere to the intima. EVs derived from foam cells have been demonstrated to stimulate vascular SMC migration and activate extracellular signal-regulated kinase (ERK) pathways, enabling the progression of aggravated lesions ${ }^{38}$. Oxidized low-density lipoproteins, from internalization into EVs, can be transferred from foam cells to vascular SMCs and endothelial cells. The resident precursors act as destructive stimuli, inducing oxidative stress and disintegration of the endothelial barrier. It has been established that several transcriptional factors, such as Krüppel-like factor-5 (KLF5), JunD (a member of the activated protein-1 family of transcription factors), and nuclear factor erythroid 2-related factor 2 (Nrf2), were found to be incorporated into EVs derived from macrophages. Consequently, EVs mediating the proliferation and migration of vascular SMCs via supply of transcription factors- play a pivotal role in adverse vascular remodeling and atherosclerotic plaque shaping while suppressing oxidative homeostasis in target cells of the vasculature; however, they can attenuate angiopoietin capacity ${ }^{38,39}$.

There is convincing evidence that a large number of non-coding RNAs, including microRNA146a, microRNA-128, microRNA-185, microRNA199a-5p, microRNA-365 and microRNA-503, are transmitted between immune cells and target somatic cells (such as epithelial cells, progenitor endothelial cells and SMCs), promoting specific signals for suppression of aerobic glycolysis, promoting macrophage polarization, and decreasing cell migration $^{39,40}$. Interestingly, delivery of microRNA146a from macrophage-released EVs repressed the expression of target genes of insulin-like growth factor 2 mRNA-binding protein 1 (IGF2BP1) and human antigen $\mathrm{R}$ or ELAV-like RNA-binding protein 1 (HuR) in naïve macrophages ${ }^{40}$. These genes activate downstream cascades, including that of NLRP3 inflammasome, and support Toll-like receptor (TLR) signaling and endoplasmic reticulum stress responses, thereby hampering recruitment of circulating monocytes and macrophages into the vascular intima $^{41}$. Nonetheless, microRNA-223 contained in macrophage-released EVs was found to be a powerful trigger for macrophage turn-over into foam cells in atherosclerotic plaques ${ }^{41}$. Moreover, microRNA199a-5p can exert its effect by targeting Klotho, which induces polarization of M2 macrophages through the TLR-4 pathway ${ }^{42}$.

There is a large body of evidence that shows macrophages can secrete so-called atherogenic exosomes containing microRNAs (-21-3p, -133a, -141$3 p)$ to mediate cell-to-cell crosstalk and encourage pro-atherogenic phenotypes of vascular SMCs ${ }^{43-45}$. Indeed, EVs enriched by microRNA-21-3p and derived from plaque-resident macrophages increase vascular SMC migration and proliferation via their phosphatase and tension homology ${ }^{43}$. The package of microRNA-133a in macrophage secretome is associated with a negative regulation of cell proliferation, inflammatory factor secretion, and apoptosis in vascular wall and plaque by modulating FGF- ${ }^{44}$. Animal studies have revealed that microRNA-141-3p deletion reverses the positive effects on vascular SMCs via long non-coding RNA-taurine-upregulated gene $1^{45}$. Thus, macrophages modulate pro-inflammatory and pro-atherogenic phenotypes in recipient cells via the secretion of EVs containing microRNAs.

Additionally, EVs are a powerful messenger for signals from infected cells to naïve cells. EVs released from virus-infected cells deliver viral RNA to dendritic cells and macrophages, thereby activating pattern recognition receptors (PRRs) on recipient cells, resulting in the expression of type I interferons and pro-inflammatory cytokines ${ }^{46,47}$. On the other hand, exosome-mediated secretion of a multitude of immunoregulatory proteins from APCs has been demonstrated; moreover, EVs can promote inflammasome creation and release as an alternative to caspase- $1^{48,49}$. Consequently, EVs can indirectly modulate the non-canonical secretion of pro-inflammatory cytokines IL- $\beta$ and IL-18 as a package of the inflammasome. Moreover, TLR9 activated macrophages can secrete EVs that ensure transport of various nucleic acids and $\mathrm{CpG}$ 
oligodeoxynucleotides to naïve macrophages and induce them to release chemokines and TNF- $\alpha^{50,51}$. Besides, one of the largest stress-induced proteins and molecular chaperones- glucose-regulated protein 170 (Grp170)- is highly responsible for the internalization of $\mathrm{CpG}$ oligodeoxynucleotide package and facilitates synergistic activation through GTP-binding protein Ras and MyD88-dependent signaling (MyD88/IRAK/TRAF6 kinases cascade, ERK/JNK/NF-kappaB), which ensures a subsequent enhancement in production of pro-inflammatory cytokines and nitric oxide ${ }^{52-54}$. These molecules were previously defined as triggers for proliferative responses from vascular SMCs, epithelial and endothelial cells, and resident macrophages ${ }^{55}$.

Apoptotic APC-derived EVs have been found to be core players in contributing to macrophage-mediated production of TGF-beta in vitro and in vivo ${ }^{56}$. In extracellular immune surveillance, APC-derived EVs also interacted with secreted phospholipases to generate eicosanoids, regulating the transfer of cargo into a cellular recipient ${ }^{57}$. Eicosanoids are involved in various biological functions, including modulation or modification of phenotype of the recipient cells, such as SMCs, macrophages, and endothelial progenitor cells; distal immune responses and proliferative responses from SMCs can also be modulated ${ }^{58,59}$.

Since EVs contain a wide spectrum of lipids, the final metabolic effect on target cells depends on lipids that enrich EVs and the immune phenotype of EVs. For instance, di-saturated phospholipids that are embarked by exosomes enhance their membrane rigidity and facilitate binding with circulating IgMtype immunoglobulins ${ }^{60}$. There are additional specific eliminating proteins that may favor the clearance of circulating immune complexes, IgM antibodies, and apoptotic cells by exosomes. Indeed, the phospholipase iPLA2, which is specifically associated with the endosomal and exosomal membranes, can be activated by reactive oxygen species and mediates lysophosphatidylcholine synthesis. It is recognized by IgM antibodies on the surface of EVs and specifically binds with apoptotic cells, leading to their removal from circulation ${ }^{61,62}$. Because apoptotic cells derived from macrophages and other APCs can suppress pro-inflammatory and proimmunogenic reactions through their cargo contents, altered elimination of these EVs from peripheral blood with exosomes is considered as an impaired endogenous tissue-protective mechanism ${ }^{63,64}$. In fact, apoptotic cells can induce 15-lipoxygenase and 15hydroxyeicosatetraenoic acid production, which potentiate the anti-inflammatory pathway through peroxisome proliferator-activated receptor-gamma and lipoxin A4 production, leading to maintenance of vascular integrity and prevention against atherosclerosis ${ }^{65}$.

Another pathophysiological mechanism by which exosomes released from oxidized low-density lipoprotein-stimulated macrophages influence atherosclerosis development and progression is via induction of neutrophil extracellular traps (NETs) ${ }^{66}$. Overall, NETosis is a unique cell death mechanism that is a crucial component of the adaptive immune response, linking microvascular inflammation with atherosclerosis ${ }^{67,68}$. Exosomal microRNA-146a secreted by activated macrophages promote the generation of intracellular reactive oxygen species and NET release via targeting superoxide dismutase $2^{66}$. Therefore, activation of endothelial cells with APCderived EVs can promote them to secrete exosomes embarked with microRNA-505, oxidized low-density lipoprotein, and metastasis-associated lung adenocarcinoma transcript 1 (MALAT1). Furthermore, MALAT1 and microRNA-505 containing various endothelial cell-derived EVs (mainly exosomes) are able to initiate the formation of NETs and plaque resident dendritic cell maturation, which in turn deteriorate atherosclerosis ${ }^{68-70}$. Indeed, transcripts of long non-coding RNAs found in EVs related to atherosclerosis have included many molecules, such as ANRIL, SENCR, CoroMarker, LIPCAR, HIF1 $\alpha$-AS1, LncRNA H19, APPAT, KCNQ1OT1, LncPPAR $\delta$, LincRNA-p21, MALAT1, MIAT, and $\mathrm{UCA}^{71}$. Some of them, such as CoroMarker, have predictive value for coronary artery disease ${ }^{72,73}$. On the other hand, animal studies have revealed that exosomal MALAT1 enhances autophagy and survival in oxidized low-density lipoprotein-treated human umbilical vein endothelial cells through suppression of microRNA-216a-5p, and that regulation of Beclin-1 expression can lead to vascular protection ${ }^{74}$. Consequently, the secretome of APC-derived EVs can play a dual role in atherosclerosis development and progression, depending on the compounds incorporated in the $\mathrm{EVs}^{75}$.

\section{FUTURE INVESTIGATIONS}

Since circulating EVs are enriched with various subtypes of biologically active molecules and can be derived from individual APCs, single EV analysis might have practical utility to identify patients at high-risk for atherosclerosis by evaluating EV numbers and the cargo composition. Perhaps, extensive clinical studies are required to evaluate whether EVs derived from cells, including APCs, could serve as potential biomarkers of subclinical atherosclerosis. Finally, an 
exosome-based therapeutic strategy can also be used to attenuate atherosclerotic heart disease and promote cardiovascular regeneration.

\section{CONCLUSION}

EVs derived from APCs play a central role in accelerating atherosclerosis through their participation in microvascular inflammation, angiogenesis, coagulation, and NETosis. While limited, there is strong evidence in the literature for APC-derived EVs as potential diagnostic and predictive markers but this requires further investigations. Large clinical trials can help deepen our understanding of APC-derived EVs as potential surrogate biomarkers of atherosclerosisassociated diseases.

\section{ABBREVIATIONS}

Apo: apo-lipoproteins

CD: cluster of differentiation

CV: cardiovascular

CVD: cardiovascular disease

EGF: Epidermal Growth Factor

ESCRT: endosomal sorting complex required for transport

FGF: fibroblast growth factor

HSP: heat shock proteins

INF: interferon

MAPk: mitogen-activated protein kinase

MFGE8: milk fat globule-EGF factor 8 protein

NF- $\kappa$ B: nuclear factor- $\kappa$ B

PDCD6IP: programmed cell death 6 interacting protein

PDGF: platelet-derived growth factor

SNARE: soluble N-ethylmaleimide-sensitive attachment protein receptor

TNF: tumor necrosis factor

TSG101: tumor susceptibility gene 101 protein

VEGF-A: vascular endothelial growth factor-A

\section{ACKNOWLEDGMENTS}

None.

\section{AUTHOR'S CONTRIBUTIONS}

Berezin AE and Berezin AA have equal responsible for the paper. All authors read and approved the final manuscript.

\section{FUNDING}

None.

\section{AVAILABILITY OF DATA AND MATERIALS}

Not applicable.

\section{ETHICS APPROVAL AND CONSENT TO PARTICIPATE}

Not applicable.

\section{CONSENT FOR PUBLICATION}

Not applicable.

\section{COMPETING INTERESTS}

The authors declare that they have no competing interests.

\section{REFERENCES}

1. Turturici G, Tinnirello R, Sconzo G, Geraci F. Extracellular membrane vesicles as a mechanism of cell-to-cell communication: advantages and disadvantages. Am J Physiol Cell Physiol. 2014; 306(7):C621-33;PMID: 24452373. Available from: https://doi.org/10.1152/ajpcell.00228.2013.

2. Greening DW, Simpson RJ. Understanding extracellular vesicle diversity - current status. Expert Rev Proteomics. 2018; 15(11):887-910;PMID: 30326765. Available from: https://doi. org/10.1080/14789450.2018.1537788.

3. Berezin AE. Microparticles in Chronic Heart Failure. Adv Clin Chem. 2017; 81:1-41;PMID: 28629587. Available from: https: //doi.org/10.1016/bs.acc.2017.01.001.

4. Abels ER, Breakefield XO. Introduction to Extracellular Vesicles: Biogenesis, RNA Cargo Selection, Content, Release, and Uptake. Cell Mol Neurobiol. 2016; 36(3):301-12;PMID: 27053351. Available from: https://doi.org/10.1007/s10571-016-0366-z.

5. Zhang B, Yeo RW, Tan KH, Lim SK. Focus on Extracellular Vesicles: Therapeutic Potential of Stem Cell-Derived Extracellular Vesicles. Int J Mol Sci. 2016; 17(2):174;PMID: 26861305. Available from: https://doi.org/10.3390/ijms17020174.

6. Ciardiello C, Cavallini L, Spinelli C, Yang J, Reis-Sobreiro M, de Candia P, Minciacchi VR, Di Vizio D. Focus on Extracellular Vesicles: New Frontiers of Cell-to-Cell Communication in Cancer. Int J Mol Sci. 2016; 17(2):175;PMID: 26861306. Available from: https://doi.org/10.3390/ijms17020175.

7. Mathieu M, Martin-Jaular L, Lavieu G, Théry C. Specificities of secretion and uptake of exosomes and other extracellular vesicles for cell-to-cell communication. Nat Cell Biol. 2019; 21(1):9-17;PMID: 30602770 . Available from: https://doi.org/10. 1038/s41556-018-0250-9.

8. D'Souza-Schorey C, Schorey JS. Regulation and mechanisms of extracellular vesicle biogenesis and secretion. Essays Biochem. 2018;62(2):125-133;PMID: 29666210. Available from: https://doi.org/10.1042/EBC20170078.

9. Todorova D, Simoncini S, Lacroix R, Sabatier F, Dignat-George F. Extracellular Vesicles in Angiogenesis. Circ Res. 2017; 120(10):1658-1673;PMID: 28495996. Available from: https: //doi.org/10.1161/CIRCRESAHA.117.309681.

10. Hafiane A, Daskalopoulou SS. Extracellular vesicles characteristics and emerging roles in atherosclerotic cardiovascular disease. Metabolism. 2018; 85:213-222;PMID: 29727628. Available from: https://doi.org/10.1016/j.metabol.2018.04.008.

11. Libby P, Ridker PM, Hansson GK. Progress and challenges in translating the biology of atherosclerosis. Nature. 2011; 473(7347):317-25;PMID: 21593864. Available from: https:// doi.org/10.1038/nature10146.

12. Tada H, Nohara A, Inazu A, Mabuchi H, Kawashiri MA. Remnant lipoproteins and atherosclerotic cardiovascular disease. Clin Chim Acta. 2019;490:1-5;PMID: 30553862. Available from: https://doi.org/10.1016/j.cca.2018.12.014.

13. Cai $X$, Zhang $Y$, Li M, Wu JH, Mai L, Li J, Yang Y, Hu Y, Huang $Y$. Association between prediabetes and risk of all cause mortality and cardiovascular disease: updated meta-analysis. BMJ. 2020; 370:m2297;PMID: 32669282. Available from: https://doi. org/10.1136/bmj.m2297. 
14. Bäck M, Hansson GK. Anti-inflammatory therapies for atherosclerosis. Nat Rev Cardiol. 2015; 12(4):199-211;PMID: 25666404. Available from: https://doi.org/10.1038/nrcardio. 2015.5 .

15. Winkels $H$, Ehinger $E$, Vassallo $M$, Buscher $K$, Dinh HQ, Kobiyama K, Hamers AAJ, Cochain C, Vafadarnejad E, Saliba AE, Zernecke A, Pramod AB, Ghosh AK, Anto Michel N, Hoppe N, Hilgendorf I, Zirlik A, Hedrick CC, Ley K, Wolf D. Atlas of the Immune Cell Repertoire in Mouse Atherosclerosis Defined by Single-Cell RNA-Sequencing and Mass Cytometry. Circ Res. 2018; 122(12):1675-1688;Available from: 10.1161/ CIRCRESAHA.117.312513.

16. Gomez D, Owens GK. Smooth muscle cell phenotypic switching in atherosclerosis. Cardiovasc Res. 2012; 95(2):15664;PMID: 22406749. Available from: https://doi.org/10.1093/ cvr/cvs115.

17. Aimo A, Migliorini P, Vergaro G, Franzini M, Passino C, Maisel A, Emdin M. The IL-33/ST2 pathway, inflammation and atherosclerosis: Trigger and target? Int J Cardiol. 2018; 267:188-192;PMID: 29793758. Available from: https://doi.org/ 10.1016/j.ijcard.2018.05.056

18. Ayada K, Yokota K, Kobayashi K, Shoenfeld Y, Matsuura E, Oguma K. Chronic infections and atherosclerosis. Ann N Y Acad Sci. 2007; 1108:594-602;PMID: 17894024. Available from: https://doi.org/10.1196/annals.1422.062.

19. Chmiela M, Gajewski A, Rudnicka K. Helicobacter pylori vs coronary heart disease - searching for connections. World J Cardiol. 2015;7(4):187-203;PMID: 25914788. Available from: https://doi.org/10.4330/wjc.v7.i4.187.

20. Millon A, Canet-Soulas E, Boussel L, Fayad Z, Douek P. Animal models of atherosclerosis and magnetic resonance imaging for monitoring plaque progression. Vascular. 2014; 22(3):22137;PMID: 24907292. Available from: https://doi.org/10.1177/ 1708538113478758.

21. Deng W, Tang T, Hou Y, Zeng Q, Wang Y, Fan W, Qu S. Extracellular vesicles in atherosclerosis. Clin Chim Acta. 2019; 495:109117;PMID: 30959044. Available from: https://doi.org/10.1016/ j.cca.2019.04.051.

22. Peng $M$, Liu X, Xu G. Extracellular Vesicles as Messengers in Atherosclerosis. J Cardiovasc Transl Res. 2020; 13(2):121-130. doi: 10.1007/s12265-019-09923-z. ;PMID: 31664614. Available from: https://doi.org/10.1007/s12265-019-09923-z.

23. Ramis JM. Extracellular Vesicles in Cell Biology and Medicine. Sci Rep. 2020; 10, 8667;PMID: 32439963. Available from: https: //doi.org/10.1038/s41598-020-65826-z.

24. Théry C, et al. Minimal information for studies of extracellular vesicles 2018 (MISEV2018): a position statement of the International Society for Extracellular Vesicles and update of the MISEV2014 guidelines. J Extracell Vesicles. 2018;7(1):1535750. PMID: 30637094. Available from: 10.1080/20013078.2018 1535750.

25. Boilard E. Extracellular vesicles and their content in bioactive lipid mediators: more than a sack of microRNA. J Lipid Res. 2018; 59(11):2037-2046;PMID: 29678959. Available from: https://doi.org/10.1194/jlr.R084640.

26. Turchinovich A, Drapkina O, Tonevitsky A. Transcriptome of Extracellular Vesicles: State-of-the-Art. Front Immunol. 2019;PMID: 30873152. Available from: https://doi.org/10. 3389/fimmu.2019.00202.

27. Witwer KW, Théry C. Extracellular vesicles or exosomes? On primacy, precision, and popularity influencing a choice of nomenclature. J Extracell Vesicles. 2019; 8(1):1648167;PMID: 31489144. Available from: https://doi.org/10.1080/20013078. 2019.1648167.

28. Lindenbergh MFS, Stoorvogel W. Antigen Presentation by Extracellular Vesicles from Professional Antigen-Presenting Cells. Annu Rev Immunol. 2018; 36:435-459;PMID: 29400984. Available from: https://doi.org/10.1146/annurev-immunol041015-055700.

29. Saha B, Momen-Heravi F, Kodys K, Szabo G. MicroRNA Cargo of Extracellular Vesicles from Alcohol-exposed Monocytes Signals Naive Monocytes to Differentiate into M2 Macrophages.
J Biol Chem. 2016; 291(1):149-59;PMID: 26527689. Available from: https://doi.org/10.1074/jbc.M115.694133.

30. Graff JW, Dickson AM, Clay G, McCaffrey AP, Wilson ME. Identifying functional microRNAs in macrophages with polarized phenotypes. J Biol Chem. 2012; 287(26):21816-25;PMID: 22549785. Available from: https://doi.org/10.1074/jbc.M111. 327031.

31. Mosser DM, Edwards JP. Exploring the full spectrum of macrophage activation. Nat Rev Immunol. 2008; 8(12):958 69;PMID: 19029990. Available from: https://doi.org/10.1038/ nri2448.

32. György B, Szabó TG, Pásztói M, Pál Z, Misják P, Aradi B, László V, Pállinger E, Pap E, Kittel A, Nagy G, Falus A, Buzás El. Membrane vesicles, current state-of-the-art: emerging role of extracellular vesicles. Cell Mol Life Sci. 2011; 68(16):2667 88;PMID: 21560073. Available from: https://doi.org/10.1007/ s00018-011-0689-3.

33. Choi DS, Kim DK, Kim YK, Gho YS. Proteomics, transcriptomics and lipidomics of exosomes and ectosomes. Proteomics. 2013;13(10-11):1554-71;PMID: 23401200. Available from: https://doi.org/10.1002/pmic.201200329.

34. Wagschal A, Najafi-Shoushtari SH, Wang L, Goedeke L, Sinha S, deLemos AS, Black JC, Ramírez CM, Li Y, Tewhey R, Hatoum I, Shah N, Lu Y, Kristo F, Psychogios N, Vrbanac V, Lu YC, Hla T, de Cabo R, Tsang JS, Schadt E, Sabeti PC, Kathiresan S, Cohen DE, Whetstine J, Chung RT, Fernández-Hernando C, Kaplan LM, Bernards A, Gerszten RE, Näär AM. Genome-wide identification of microRNAs regulating cholesterol and triglyceride homeostasis. Nat Med. 2015; 21(11):1290-7;PMID: 26501192. Available from: https://doi.org/10.1038/nm.3980.

35. Chen F, Chen J, Yang L, Liu J, Zhang X, Zhang Y, Tu Q, Yin $D$, Lin $D$, Wong PP, Huang $D$, Xing $Y$, Zhao J, Li M, Liu $Q$, Su F, Su S, Song E. Extracellular vesicle-packaged HIF-1 $\alpha$ stabilizing IncRNA from tumour-associated macrophages regulates aerobic glycolysis of breast cancer cells. Nat Cell Biol. 2019; 21(4):498-510;PMID: 30936474. Available from: https //doi.org/10.1038/s41556-019-0299-0.

36. Deng W, Tang T, Hou Y, Zeng Q, Wang Y, Fan W, Qu S. Extracellular vesicles in atherosclerosis. Clin Chim Acta. 2019; 495:109117;PMID: 30959044. Available from: https://doi.org/10.1016/ j.cca.2019.04.051.

37. Peng M, Liu X, Xu G. Extracellular Vesicles as Messengers in Atherosclerosis. J Cardiovasc Transl Res. 2020;13(2):121-130. ;PMID: 31664614. Available from: https://doi.org/10.1007/ s12265-019-09923-z.

38. Berezin A. Neutrophil extracellular traps: The core player in vascular complications of diabetes mellitus. Diabetes Metab Syndr. 2019;13(5):3017-3023;PMID: 30030160. Available from: https://doi.org/10.1016/j.dsx.2018.07.010.

39. Nguyen MA, Karunakaran D, Geoffrion M, Cheng HS, Tandoc K, Perisic Matic L, Hedin U, Maegdefessel L, Fish JE, Rayner KJ. Extracellular Vesicles Secreted by Atherogenic Macrophages Transfer MicroRNA to Inhibit Cell Migration. Arterioscler Thromb Vasc Biol. 2018; 38(1):49-63;PMID: 28882869. Available from: https://doi.org/10.1161/ATVBAHA.117.309795.

40. Duewell P, Kono H, Rayner KJ, Sirois CM, Vladimer G, Bauernfeind FG, Abela GS, Franchi L, Nuñez G, Schnurr M, Espevik T, Lien E, Fitzgerald KA, Rock KL, Moore KJ, Wright SD, Hornung $V$, Latz E. NLRP3 inflammasomes are required for atherogenesis and activated by cholesterol crystals. Nature. 2010; 464(7293):1357-61. doi: 10.1038/nature08938. Erratum in: Nature. 2010; 466(7306): 652;PMID: 20428172. Available from: https://doi.org/10.1038/nature08938.

41. Ismail N, Wang Y, Dakhlallah D, Moldovan L, Agarwal K, Batte K, Shah P, Wisler J, Eubank TD, Tridandapani S, Paulaitis ME, Piper MG, Marsh CB. Macrophage microvesicles induce macrophage differentiation and miR-223 transfer. Blood. 2013; 121(6):984-95;PMID: 23144169. Available from: https: //doi.org/10.1182/blood-2011-08-374793.

42. Jia Y, Zheng Z, Xue M, Zhang S, Hu F, Li Y, Yang Y, Zou M, Li S, Wang $L$, Guan $M$, Xue Y. Extracellular Vesicles from Albumin- 
Induced Tubular Epithelial Cells Promote the M1 Macrophage Phenotype by Targeting Klotho. Mol Ther. 2019; 27(8):14521466;PMID: 31208912. Available from: https://doi.org/10. 1016/j.ymthe.2019.05.019.

43. Zhu J, Liu B, Wang Z, Wang D, Ni H, Zhang L, Wang Y. Exosomes from nicotine-stimulated macrophages accelerate atherosclerosis through miR-21-3p/PTEN-mediated VSMC migration and proliferation. Theranostics. 2019; 9(23):69016919;PMID: 31660076. Available from: https://doi.org/10. 7150/thno. 37357.

44. Zhang L, Cheng H, Yue Y, Li S, Zhang D, He R. TUG1 knockdown ameliorates atherosclerosis via up-regulating the expression of miR-133a target gene FGF1. Cardiovasc Pathol. 2018; 33:615;PMID: 29268138. Available from: https://doi.org/10.1016/j. carpath.2017.11.004.

45. Tang $Y$, Hu J, Zhong Z, Liu Y, Wang Y. Long Noncoding RNA TUG1 Promotes the Function in ox-LDL-Treated HA-VSMCs via miR-141-3p/ROR2 Axis. Cardiovasc Ther. 2020 May 29; 2020: 6758934;PMID: 32565910. Available from: https://doi.org/10. $1155 / 2020 / 6758934$.

46. Okamoto $M$, Tsukamoto $H$, Kouwaki T, Seya T, Oshiumi H. Recognition of Viral RNA by Pattern Recognition Receptors in the Induction of Innate Immunity and Excessive Inflammation During Respiratory Viral Infections. Viral Immunol. 2017; 30(6): 408-420;PMID: 28609250. Available from: https://doi.org/10. 1089/vim.2016.0178.

47. Kouwaki T, Okamoto M, Tsukamoto H, Fukushima $Y$, Oshiumi $\mathrm{H}$. Extracellular Vesicles Deliver Host and Virus RNA and Regulate Innate Immune Response. Int J Mol Sci. 2017;18(3):666;PMID: 28335522. Available from: https://doi. org/10.3390/ijms18030666.

48. Cypryk W, Nyman TA, Matikainen S. From Inflammasome to Exosome-Does Extracellular Vesicle Secretion Constitute an Inflammasome-Dependent Immune Response? Front Immunol. 2018;9:2188;PMID: 30319640. Available from: https: //doi.org/10.3389/fimmu.2018.02188.

49. Tabas I, Garcia-Cardena G, Owens GK. Recent insights into the cellular biology of atherosclerosis. The Journal of Cell Biology. 2015; 209(1):13-22;PMID: 25869663. Available from: https:// doi.org/10.1083/jcb.201412052.

50. Zhang $Y$, Jin $X$, Liang J, Guo $Y$, Sun G, Zeng $X$, Yin H. Extracellular vesicles derived from ODN-stimulated macrophages transfer and activate $\mathrm{Cdc} 42$ in recipient cells and thereby increase cellular permissiveness to EV uptake. Sci Adv. 2019; 5(7): eaav1564;PMID: 31355328. Available from: https://doi. org/10.1126/sciadv.aav1564.

51. Calderwood SK, Gong J, Murshid A. Extracellular HSPs: The Complicated Roles of Extracellular HSPs in Immunity. Front Immunol. 2016;7:159;Available from: https://doi.org/10.3389/ fimmu.2016.00159.

52. Zuo D, Yu X, Guo C, Yi H, Chen X, Conrad DH, Guo TL, Chen Z, Fisher PB, Subjeck JR, Wang XY. Molecular chaperoning by glucose-regulated protein 170 in the extracellular milieu promotes macrophage-mediated pathogen sensing and innate immunity. FASEB J. 2012; 26(4):1493-505. doi: 10.1096/fj.11197707;PMID: 22207611. Available from: https://doi.org/10. 1096/fj.11-197707.

53. Xu H, An H, Yu Y, Zhang M, Qi R, Cao X. Ras participates in CpG oligodeoxynucleotide signaling through association with tolllike receptor 9 and promotion of interleukin-1 receptorassociated kinase/tumor necrosis factor receptor-associated factor 6 complex formation in macrophages. J Biol Chem. 2003; 278(38):36334-40;PMID: 12867418. Available from: https://doi.org/10.1074/jbc.M305698200.

54. Yeo SJ, Yoon JG, Yi AK. Myeloid differentiation factor 88-dependent post-transcriptional regulation of cyclooxygenase- 2 expression by CpG DNA: tumor necrosis factor-alpha receptor-associated factor 6 , a diverging point in the Toll-like receptor 9-signaling. J Biol Chem. 2003; 278(42):40590-600;PMID: 12902324. Available from: https://doi.org/10.1074/jbc.M306280200.
55. Hafiane A, Daskalopoulou SS. Extracellular vesicles characteristics and emerging roles in atherosclerotic cardiovascular disease. Metabolism. 2018; 85:213-222;PMID: 29727628. Available from: https://doi.org/10.1016/j.metabol.2018.04.008.

56. Chen H, Kasagi S, Chia C, Zhang D, Tu E, Wu R, Zanvit P, Goldberg N, Jin W, Chen W. Extracellular Vesicles from Apoptotic Cells Promote TGF $\beta$ Production in Macrophages and Suppress Experimental Colitis. Sci Rep. 2019; 9(1): 5875;PMID: 30971739. Available from: https://doi.org/10.1038/s41598019-42063-7.

57. Taha EA, Ono K, Eguchi T. Roles of Extracellular HSPs as Biomarkers in Immune Surveillance and Immune Evasion. Int J Mol Sci. 2019;20(18):4588;PMID: 31533245. Available from: https://doi.org/10.3390/ijms20184588.

58. Boilard E. Extracellular vesicles and their content in bioactive lipid mediators: more than a sack of microRNA. J Lipid Res. 2018; 59(11):2037-2046;PMID: 29678959. Available from: https://doi.org/10.1194/jlr.R084640.

59. Record M, Silvente-Poirot S, Poirot M, Wakelam MJO. Extracellular vesicles: lipids as key components of their biogenesis and functions. J Lipid Res. 2018; 59(8):1316-1324;PMID: 29764923. Available from: https://doi.org/10.1194/jlr.E086173.

60. Blanc L, Barres C, Bette-Bobillo P, Vidal M. Reticulocytesecreted exosomes bind natural lgM antibodies: involvement of a ROS-activatable endosomal phospholipase iPLA2. Blood. 2007 Nov 1; 110(9):3407-16;PMID: 17666570. Available from: https://doi.org/10.1182/blood-2007-04-085845.

61. Laulagnier K, Motta C, Hamdi S, Roy S, Fauvelle F, Pageaux JF, Kobayashi T, Salles JP, Perret B, Bonnerot C, Record M. Mast cell- and dendritic cell-derived exosomes display a specific lipid composition and an unusual membrane organization. Biochem J. 2004;380(Pt 1):161-171;PMID: 14965343. Available from: https://doi.org/10.1042/BJ20031594.

62. Blanc L, Vidal M. Reticulocyte membrane remodeling: contribution of the exosome pathway. Curr Opin Hematol. 2010; 17(3):177-83;PMID: 20173636. Available from: https://doi.org/ 10.1097/MOH.0b013e328337b4e3.

63. Freire-de-Lima CG, Xiao YQ, Gardai SJ, Bratton DL, Schiemann WP, Henson PM. Apoptotic cells, through transforming growth factor-beta, coordinately induce anti-inflammatory and suppress pro-inflammatory eicosanoid and NO synthesis in murine macrophages. J Biol Chem. 2006 Dec 15; 281(50): 38376-84;PMID: 17056601. Available from: https://doi.org/10. 1074/jbc.M605146200.

64. Wang Y, Subramanian M, Yurdagul A Jr, Barbosa-Lorenzi VC, Cai B, de Juan-Sanz J, Ryan TA, Nomura M, Maxfield FR, Tabas I. Mitochondrial Fission Promotes the Continued Clearance of Apoptotic Cells by Macrophages. Cell. 2017; 171(2):331345.e22;PMID: 28942921. Available from: https://doi.org/10. 1016/j.cell.2017.08.041.

65. Koelwyn GJ, Corr EM, Erbay E, Moore KJ. Regulation of macrophage immunometabolism in atherosclerosis. Nat Immunol. 2018; 19(6):526-537;PMID: 29777212. Available from: https://doi.org/10.1038/s41590-018-0113-3.

66. Zhang YG, Song Y, Guo XL, Miao RY, Fu YQ, Miao CF, Zhang C. Exosomes derived from oxLDL-stimulated macrophages induce neutrophil extracellular traps to drive atherosclerosis. Cell Cycle. 2019; 18(20):2674-2684;PMID: 31416388. Available from: https://doi.org/10.1080/15384101.2019.1654797.

67. Berezin A. Neutrophil extracellular traps: The core player in vascular complications of diabetes mellitus. Diabetes Metab Syndr. 2019; 13(5):3017-3023;PMID: 30030160. Available from: https://doi.org/10.1016/j.dsx.2018.07.010.

68. Gao H, Wang X, Lin C, An Z, Yu J, Cao H, Fan Y, Liang X. Exosomal MALAT1 derived from ox-LDL-treated endothelial cells induce neutrophil extracellular traps to aggravate atherosclerosis. Biol Chem. 2020; 401(3):367-376;PMID: 31318684. Available from: https://doi.org/10.1515/hsz-2019-0219.

69. Chen L, Hu L, Li Q, Ma J, Li H. Exosome-encapsulated miR505 from ox-LDL-treated vascular endothelial cells aggravates atherosclerosis by inducing NET formation. Acta Biochim Biophys Sin (Shanghai). 2019; 51(12):1233-1241;PMID: 31768526. 
Available from: https://doi.org/10.1093/abbs/gmz123.

70. Li H, Zhu X, Hu L, Li Q, Ma J, Yan J. Loss of exosomal MALAT1 from ox-LDL-treated vascular endothelial cells induces maturation of dendritic cells in atherosclerosis development. Cell Cycle. 2019; 18(18):2255-2267;PMID: $31305205 . \quad$ Available from: https://doi.org/10.1080/15384101.2019.1642068.

71. Lu S, Liang $Q$, Huang $Y$, Meng F, Liu J. Definition and review on a category of long non-coding RNA: Atherosclerosisassociated circulating IncRNA (ASCLncRNA). PeerJ. 2020; 8:e10001;PMID: 33240586. Available from: https://doi.org/10 7717/peerj.10001.

72. Yang Y, Cai Y, Wu G, Chen X, Liu Y, Wang X, Yu J, Li C, Chen X, Jose PA, Zhou L, Zeng C. Plasma long non-coding RNA, CoroMarker, a novel biomarker for diagnosis of coronary artery disease. Clin Sci (Lond). 2015;129(8):675-85;PMID: 26201019.
Available from: https://doi.org/10.1042/CS20150121.

73. Zhong W, Deng $Q$, Deng $X$, Zhong Z, Hou J. Long noncoding RNA expression profiles in peripheral blood mononuclear cells of patients with coronary artery disease. J Thorac Dis. 2020; 12(11):6813-6825;PMID: 33282383. Available from: https://doi.org/10.21037/jtd-20-3105.

74. Wang K, Yang C, Shi J, Gao T. Ox-LDL-induced InCRNA MALAT1 promotes autophagy in human umbilical vein endothelial cells by sponging miR-216a-5p and regulating Beclin-1 expression. Eur J Pharmacol. 2019; 858: 172338;PMID:31029709. Available from: https://doi.org/10.1016/j.ejphar.2019.04.019.

75. Wang Y, Xie Y, Zhang A, Wang M, Fang Z, Zhang J. Exosomes: An emerging factor in atherosclerosis. Biomed Pharmacother. 2019; 115:108951;PMID: 31078042. Available from: https: //doi.org/10.1016/j.biopha.2019.108951. 